\title{
Uso de agar-agar para la elaboración de gelatinas transparente talladas en 3D
}

Use of agar-agar for the elaboration of transparent gelatins carved in $3 D$

DOI: https://doi.org/10.33262/rmc.v6i2.1249

\author{
Karina Patricia Llerena Oñate ${ }^{1}$ \\ Instituto Luis A. Martínez Agronómico, Ecuador \\ https://orcid.org/0000-0002-0443-1436. \\ kllerena@institutos.gob.ec \\ patymau_28@hotmail.com
}

\section{RESUMEN}

Introducción. La gelatina es un ingrediente multifuncional que utiliza como agente gelificante en la industria de alimentos, además, es una fuente de colágeno. Los agentes gelificantes se agregan a los medios microbianos líquidos para convertirlos en medios semisólidos o sólidos. El agar de calidad alimentaria es una alternativa la preparación de medios microbiológicos sólidos y es comparable al agar bacteriológico en términos de sus propiedades de gelificación y estabilidad. Objetivo. Evaluar el uso de agar - agar como agente gelificante en las características organolépticas para la elaboración de la gelatina tallada en 3D. Metodología. Se aplicó un diseño experimental para la elaboración de gelatina tallada en 3D, se utilizó 4 tratamiento, de los cuales 3 fueron de agar con concentraciones de 0,2\%, 0,35\% y 0,45\%. Además, se ejecutó un análisis sensorial para evaluar aspectos como textura, sabor, transparencia y aroma. Resultados. Se obtuvo que la composición de agar con el 0,35\% desarrollo mejores propiedades organolépticas, por otra parte, el sabor y color no tuvieron resultados significativos, no obstante, la textura mantuvo una significancia considerable. Conclusión. La combinación de un agente gelificante (agar) y gelatina tiene la capacidad de transferir a las gelatinas talladas en 3D resistencia y flexibilidad, lo que ocasiona, que la gelatina se mantenga en altas temperaturas. Además, el tratamiento más favorable demostró mediante un análisis microbiológico que se cumple con la normativa ecuatoriana.

PALABRAS CLAVE: Agar; Agentes gelificantes; Gelatina; Propiedades organolépticas

\section{ABSTRACT}


Introduction. Gelatin is a multifunctional ingredient used as a gelling agent in the food industry, in addition, it is a source of collagen. Gelling agents are added to liquid microbial media to convert them to semi-solid or solid media. Food grade agar is an alternative to solid microbiological media preparation and is comparable to bacteriological agar in terms of its gelling properties and stability. Objective. Evaluate the use of agar-agar as a gelling agent in the organoleptic characteristics for the elaboration of 3D carved gelatin. Methodology. An experimental design was applied for the elaboration of 3D carved gelatin, 4 treatments were used, of which 3 were agar with concentrations of $0.2 \%, 0.35 \%$ and $0.45 \%$. In addition, a sensory analysis was carried out to evaluate aspects such as texture, flavor, transparency and aroma. Results. It was obtained that the agar composition with $0.35 \%$ developed better organoleptic properties, on the other hand, the flavor and color did not have significant results, however, the texture maintained considerable significance. Conclusion. The combination of a gelling agent (agar) and gelatin has the ability to transfer strength and flexibility to 3D-cut gelatins, which causes the gelatin to remain at high temperatures. In addition, the most favorable treatment was demonstrated by a microbiological analysis that it complies with the Ecuadorian regulations.

KEYWORDS: Agar; Gelling agents; Jelly; Organoleptic properties

\section{INTRODUCCIÓN}

La gelatina es un polímero natural que está hecho de la degradación hidrolítica de la proteína del colágeno y su estructura distintiva de aminoácidos le confiere varios beneficios médicos. Generalmente, la gelatina está en forma de tabletas, gránulos o polvos $\mathrm{y}$, a veces, se puede disolver en agua antes de su uso, es ampliamente explorada por los investigadores como una matriz para el cultivo celular tridimensional y como un componente de los andamios de ingeniería de tejidos. La gelatina tiene un alto contenido de proteínas en ciertos alimentos nutricionalmente equilibrados y puede sustituir las grasas y los carbohidratos y es libre de grasas y colesterol con alto contenido de proteínas (Alipal et al., 2020).

La gelatina es un ingrediente multifuncional que se ha utilizado durante mucho tiempo en la industria alimentaria como agente gelificante, espesante y formador de película, así como como emulsionante y estabilizador. La fuente de colágeno y el proceso de fabricación inciden significativamente en las propiedades fisicoquímicas y funcionales de 
la gelatina (Rehman et al., 2016). La producción tradicional de gelatina implica el pretratamiento de la materia prima seguida de pasos de extracción y purificación y generalmente se usa ácido o álcali en las etapas de pretratamiento para eliminar las impurezas y escindir los enlaces cruzados de colágeno, luego la gelatina se produce mediante una desnaturalización térmica parcial del colágeno (Du et al., 2014).

En la actualidad, en Ecuador la elaboración de alimentos en 3D ofrece una variedad de beneficios potenciales, incluso tienen el potencial de ser saludable y bueno para el medio ambiente porque puede ayudar a convertir ingredientes alternativos como proteínas de algas, hojas de remolacha o insectos en productos sabrosos. También abre la puerta a la personalización de los alimentos y, por lo tanto, se adapta a las necesidades y preferencias individuales, lo que ha dado auge a la elaboración de gelatina 3D. Sin embargo, la comercialización es el proceso final de la gelatina, pero en este punto el transporte de los alimentos en $3 \mathrm{D}$ ha generado ciertas complicaciones debido a la temperatura que se requiere para mantener a los alimentos, esto se ve afectado aún más hasta en la región costa, por tal motivo, las formulaciones para la elaboración de la gelatina dependerán en función al clima. En función a lo descrito hasta este punto, el objetivo de este estudio fue evaluar el uso de agar - agar como agente gelificante en las características organolépticas para la elaboración de la gelatina tallada en 3D.

Los agentes gelificantes se agregan a los medios microbianos líquidos para convertirlos en medios semisólidos o sólidos. Generalmente, algunos polisacáridos coloidales y ciertas proteínas de origen microbiano y vegetal actúan como solidificadores o estabilizadores en el medio formando una red molecular tridimensional continua (Spotti, 2013). Los gelificantes aportan firmeza al medio e influyen en sus características de difusión. La velocidad de difusión depende de la viscosidad del medio, que posteriormente depende de la concentración y las características fisicoquímicas del agente (Marlin et al., 2012). Ciertos agentes gelificantes pueden cambiar entre estado líquido y gel dependiendo de la temperatura, una propiedad que aumenta mucho su conveniencia. Un buen solidificante tiende a ser incoloro, inodoro y un buen retenedor de humedad.

Varios mesófilos y extremófilos son actualmente incultivos o poco cultivables debido a la falta de factores bióticos y abióticos adecuados. Cada agente gelificante tiene un rango limitado de $\mathrm{pH}$ y temperatura de funcionamiento óptimo y diferentes agentes gelificantes pueden ser degradados por un conjunto diferente de microorganismos, lo que requiere la necesidad de varios agentes gelificantes. En los últimos tiempos, las fuentes tradicionales 
de agentes gelificantes se están utilizando en exceso, lo que requiere además la necesidad de nuevos agentes gelificantes.

Los medios sólidos, que se consiguen mediante la adición de agentes gelificantes al caldo líquido, son más adecuados para la separación y aislamiento de microorganismos que los medios líquidos (Noguera et al., 2018). La gelatina se utilizó para obtener el primer medio sólido en 1881 por Robert Koch. Su digestión por bacterias y la temperatura de fusión a $37^{\circ} \mathrm{C}$ limitaron su uso. Estos problemas asociados con la gelatina impulsaron la búsqueda de agentes alternativos (Hernández, 2013). El uso de agar como alternativa a la gelatina fue propuesto por primera vez por Angelina Hesse (Casas et al., 2017).

Varias ventajas del agar sobre la gelatina lo hicieron popular, ya que es estable en un amplio rango de temperatura (temperatura de solidificación entre 32 y $42{ }^{\circ} \mathrm{C}$ y temperatura de fusión alrededor de $85^{\circ} \mathrm{C}$ ) y, por lo tanto, es adecuado para el crecimiento de organismos mesófilos (Koppmann, 2011). La firmeza de los medios aumenta directamente en proporción a la concentración de agar (Das et al., 2015). Además, el agar tiene buenas características de difusión y tiene buena claridad, baja adhesividad y es metabólicamente inerte.

El agar de calidad alimentaria también se ha informado como una alternativa de bajo costo en la preparación de medios microbiológicos sólidos, el agar de calidad alimentaria es comparable al agar bacteriológico en términos de sus propiedades de gelificación y estabilidad (Villalobos et al., 2007). Sin embargo, los medios producidos con agar de calidad alimentaria tienen menos claridad que los producidos con agar bacteriológico (Greiff et al., 2015).

Existen algunos factores o medios donde la gelatina no se comporta adecuadamente estos son: las enzimas proteolíticas presentes en algunas frutas, las cuales rompen las cadenas de proteicas, esto dificulta formación de la red de gel. Preparaciones muy ácidas, la gelatina cuaja bien en un rango de $\mathrm{pH}$ de 3,5 a 10, al usar frutas muy ácidas la gelificación ocurre lentamente y forma geles menos firmes. La gelatina tolera entre 30 y $50 \%$ de alcohol en la preparación, baja concentración de alcohol aumenta la fuerza de gel. El azúcar incrementa la fuerza de gel, dado que el azúcar captura agua durante la preparación, mientras que los productos lácteos aumentan la fuerza del gel y aceleran la gelificación y la sal interfiere en la atracción entre las moléculas de gelatina y se obtienen geles más blandos (Noguera et al., 2018). 


\section{MATERIALES Y MÉTODOS}

Se realizó un estudio de diseño experimental ejecutado en un laboratorio especializado para el procesamiento de alimentos, como materia prima se consideró al agar como agente, además se utilizó gelatina sin sabor, crema vegetal y colorantes vegetales, todos los elementos utilizados cumplen con los parámetros de calidad alimentaria.

En la figura 1, se describe la preparación de la gelatina base para el tallado en 3D.

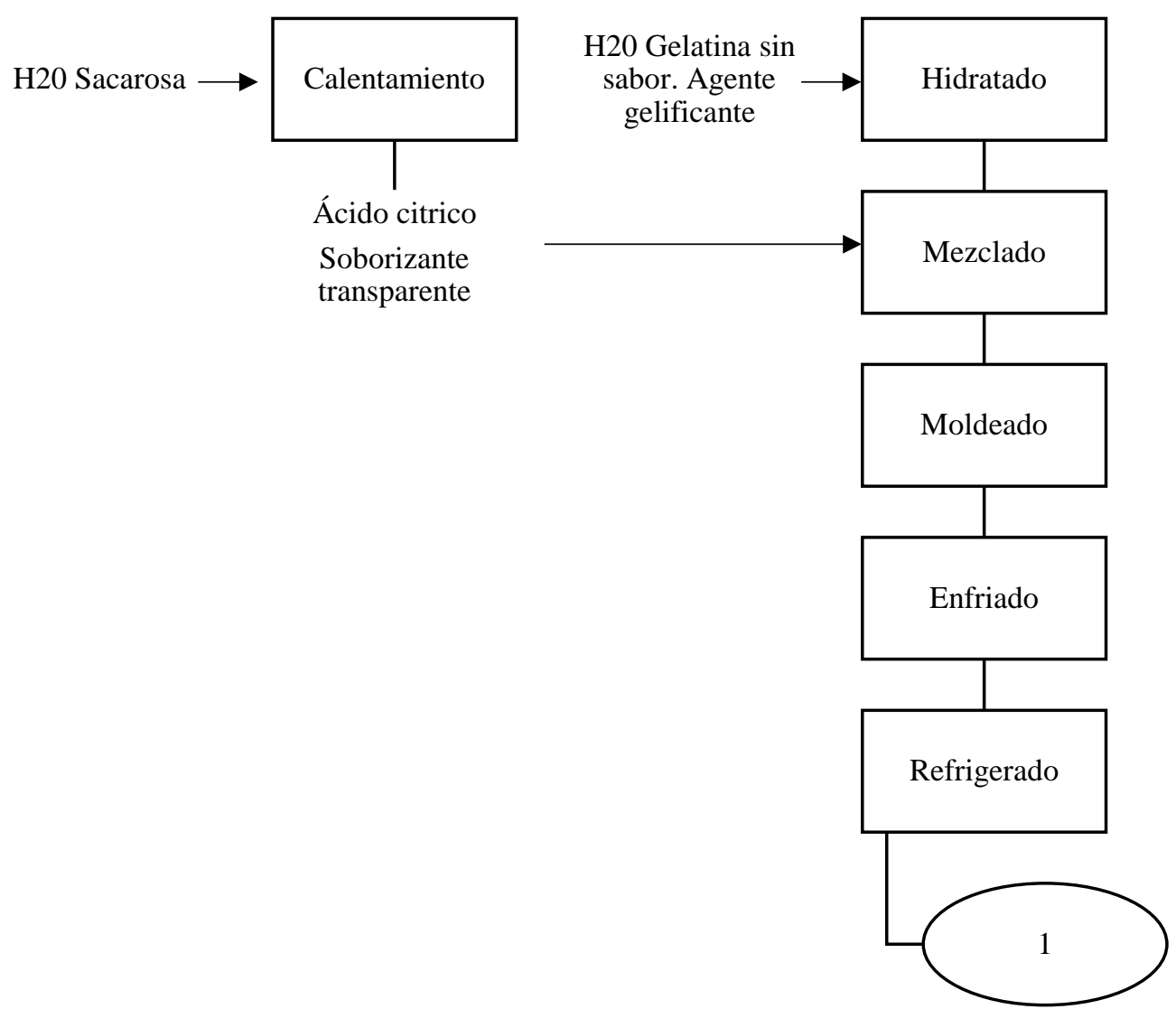

Figura 1. Diagrama de flujo del proceso de elaboración de la gelatina base o transparente.

Por consiguiente, el proceso inicio con la preparación de la gelatina transparente, en un recipiente de acero inoxidable se colocó 1 litro de agua purificada y se procedió a mezclar 250 gramos de sacarosa, para posteriormente elevar la temperatura de la mezcla realizada hasta llegar al punto de ebullición. Ahora, se continuo con la hidratación, por lo cual, en temperatura ambiente se mezcló el agente gelificante agar con 200 mililitros de agua hervida y 50 gramos de gelatina sin sabor, la mezcla requirió 5 minutos para su reposo. En este punto del proceso se mezcló la solución de sacarosa con la gelatina hidratada, para obtener una mezcla homogénea se agito la preparación con 5mililitros de saborizante 
transparente y 5 gramos de ácido cítrico. Para finalizar la preparación, en moldes de polipropileno se agregó 80 gramos de la gelatina, iniciando así el proceso de enfriamiento por 45 minutos a temperatura ambiente y posterior al enfriamiento por 120 minutos se refrigero la gelatina.

Una vez que la gelatina estuvo lista, con una jeringa de 5 mililitros se introdujo gelatina de leche en la gelatina transparente, moldeando de esta manera figuras en tres dimensiones florales. Al finalizar el tallado, se cubrió cada molde de gelatina con 20 gramos de gelatina de leche, enviando así el producto final a refrigeración por una hora, finalizando la etapa de refrigeración se inició con el desmoldado, se introdujo agua caliente en los moldes por 3 segundos y se lo coloco en empaques de polipropileno transparente. Una vez finalizado todo el proceso, la gelatina se mantuvo refrigerada para mantener las características organolépticas.

En consideración al agente agar, se pudo trabajar con 3 concentraciones con un diseño de $2 \times 3$, de 0,35 y $0,45 \mathrm{~m} / \mathrm{m}$. En la figura 2 , se detalla el número de tratamientos y cada concentración del agente gelificante.

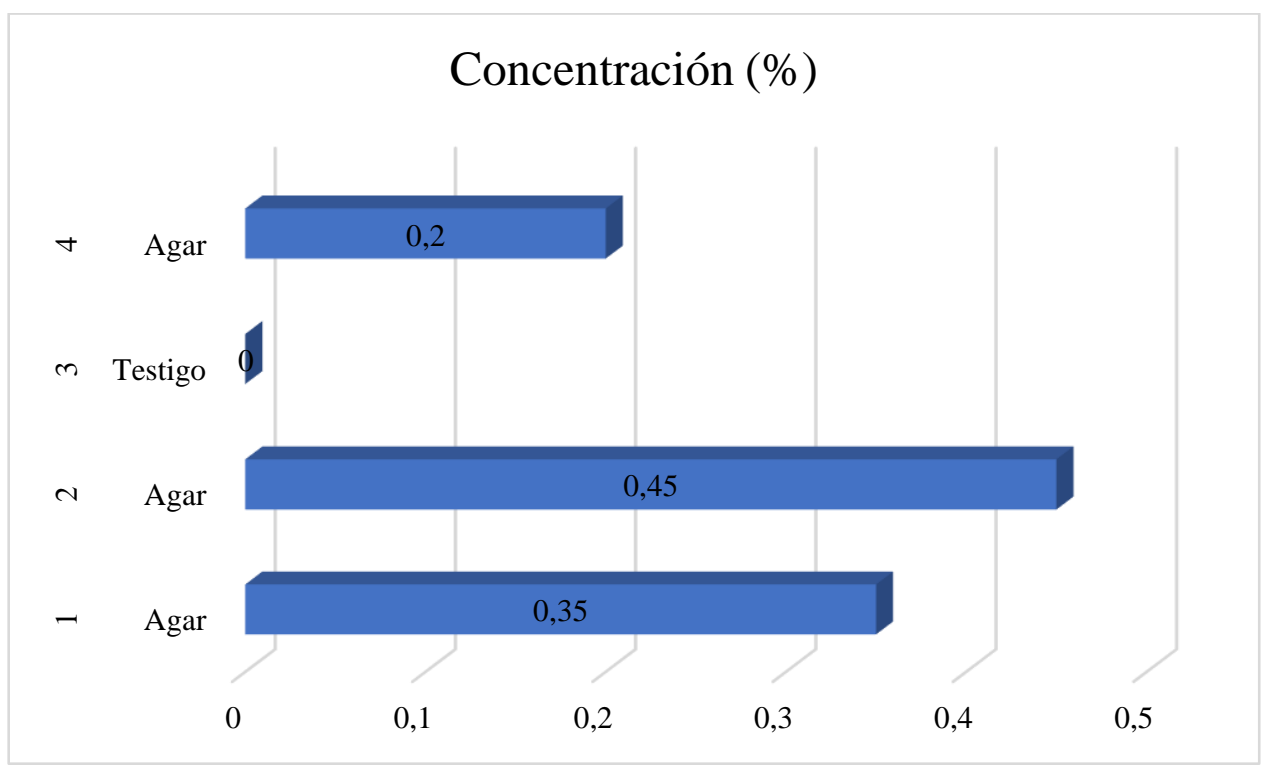

Figura 2. Cantidad de tratamientos evaluados

Como se evidencia en la figura 2, se trabajó con tres tratamientos, adicional a esto se incluyo un tratamiento testigo, muestra que no contuvo ningún agente de gelificación, esto se realizó con la finalidad de diferenciar si el uso del agar como agente influye en las características organolépticas que se generó en la gelatina tallada en 3D.

Se convoco a 14 evaluadores como parte de la comisión semi-entrenada para el análisis sensorial, los cuales, tuvieron una capacitación previa al análisis. Para evaluar el producto se pidió que se considere textura, sabor, transparencia y aroma de las gelatinas talladas 
en 3D. Por lo establecido, se estableció un formato de evaluación de una escala no estructurada de 10 centímetros, en donde la intensidad más débil de cada punto de análisis se direccionada al lado izquierdo y por lo contrario con una intensidad fuerte se direccionada al lado derecho (ver tabla 2).

Tabla 2.

Orden de entrega de los tratamientos a cada panelista

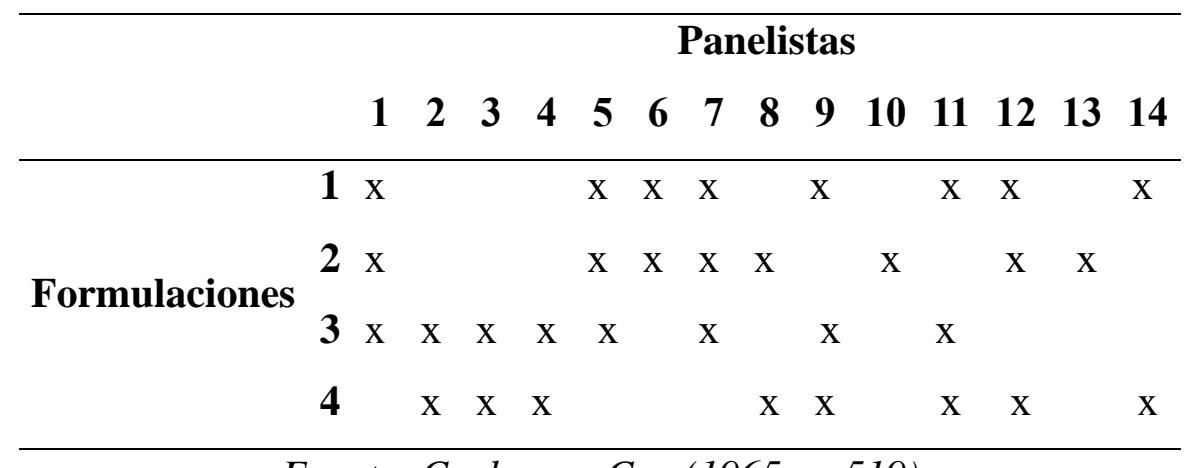

Fuente: Cochran y Cox (1965, p. 519)

Se estableció cabinas de degustación para el análisis sensorial, las formulaciones fueron servidas a $5{ }^{\circ} \mathrm{C} \pm 2{ }^{\circ} \mathrm{C}$ planteadas e identificadas con tres números colocados al azar y se entregó 4 muestras a cada evaluador.

Para la obtención de resultados, se realizó un análisis de varianza con el 95\% de confianza y el 5\% de margen de error obteniendo así las diferencias significativas mediante el programa estadístico Statgraphics Centurion ver. 15.2.06. Posterior a los resultados, a los tratamientos que emitieron buenos resultados se le realizo un análisis microbiológico.

\section{RESULTADOS Y DISCUSIÓN}

En respuesta a los análisis de los tratamientos en la tabla 2 se presenta las diferencias significativas obtenidas por procesos estadísticos. Los resultados que obtuvieron un valor $\mathrm{p}<0,05$ en el análisis de varianza de muestran que existe diferencias significativas. Como resultado, existió 4 grupos semejantes, sin embargo, se destaca el tratamiento 3, debido a que en su media tiene mayor valoración y dentro de un mismo grupo homogéneo se encuentra. 
Tabla 2.

Análisis de varianza de tratamientos de gelatina tallada en $3 D$.

\begin{tabular}{ccccc}
\hline Tratamiento & Transparencia $^{1}$ & Sabor $^{1}$ & Textura $^{1}$ & Aroma $^{1}$ \\
\hline 1 & $1,9 \pm 0,7$ (a) & $4,5 \pm 2,5$ (a) & $4,0 \pm 1,3$ (ab) & $5,5 \pm 1,5$ (a) \\
2 & $6,5 \pm 2,3$ (c) & $5,5 \pm 1,9$ (a) & $5,2 \pm 1,6$ (a) & $5,1 \pm 1,3$ (a) \\
3 & $8,8 \pm 0,7$ (d) & $5,8 \pm 2,1$ (a) & $6,0 \pm 1,4$ (b) & $5,3 \pm 1,1$ (a) \\
4 & $3,9 \pm 1,7$ (abc) & $6,2 \pm 1,9$ (a) & $3,7 \pm 1,7$ (a) & $5,9 \pm 1,5$ (a) \\
Valor $p$ & 0,0001 & 0,0865 & 0,024 & 0,0578 \\
\hline
\end{tabular}

${ }^{1}$ Tratamientos con la misma letra son estadísticamente iguales $(\mathrm{p}<0,05)$.

$$
{ }^{1} \text { Media } \pm \text { DE }(n=8) .
$$

En consideración al sabor, se identifica que no hay diferencias estadísticamente significativas, por otra parte, en los atributos de sabor y color el uso del agar no aporta a las gelatinas elaboradas y finalmente en relación a la textura si existe una diferencia estadísticamente significativa. Tanto el tratamiento 1 como el tratamiento 3 , en el resultado de la media obtuvieron una mayor valoración en comparación a los otros. Además, se encontraron dentro de un mismo grupo homogéneo.

En este punto, lo mas adecuado seria utilizar la mezcla de gelatina con agar para combinar todas las propiedades como obtener resistencia y flexibilidad a temperaturas considerablemente elevadas (Rhein et al., 2015).. En tal sentido, mencionado al tratamiento 1 (0,35 de agar), sería la opción más adecuada debido a los beneficios que generó en la gelatina tallada en 3D. El agar como agente gelificante, cuenta con características resistentes y compactas, además se estima que tiene 10 veces más de fuerza gelificante en comparación a la gelatina (Rhein et al., 2015).

El uso del agar en la gelatina aporta varias ventajas, para que el agar pueda gelificarse debe estar a $40^{\circ} \mathrm{C}$ y finaliza aproximadamente a $25^{\circ} \mathrm{C}$. En función al tiempo, el agar depende de la concentración utilizada, volumen del liquido y la temperatura ambiente en donde se encuentre el producto. En la tabla 2, se consideró el aroma de las gelatinas a lo que se obtuvo que no existe diferencias considerables, entendiendo que los evaluadores tuvieron la misma opinión.

Para finalizar, se realizó un análisis microbiológico de la gelatina con agar $(0,35 \%$ de contenido), como resultados representativos se obtuvo que tanto en hongos y microorganismo fue $<10 \mathrm{UPC} / \mathrm{g}$. En función a los resultados microbiológicos se entiende 
que los resultados se encuentran bajo la norma del Ecuador (Norma Técnica Ecuatoriana, 2019). Los especificaciones que solicita la norma es que las gelatinas se encuentre sin grumos en consideración a su aspecto, por otra parte, el color debe ser uniforme y el olor debe ser característico al que se este utilizando en la elaboración (Norma Técnica Ecuatoriana, 2019).

\section{CONCLUSIONES}

Este estudio, concluye que al incorporar agentes gelificantes como fue el agar influye de forma directa en las características sensoriales organolépticas de la gelatina tallada en 3D, se trabajó con 4 tratamiento de los cuales 3 fueron de agar con diferente composición y 1 fue testigo, de los tratamientos con agar el de composición de $0,35 \mathrm{~m} / \mathrm{m}$, fue la que presentó los resultados más favorables para las características organolépticas.

Al combinar gelatina con el agar como agente gelificante se transfiere los agentes de cada elemento como en este estudio fue una mayor resistencia y una mejor flexibilidad consistencia que se puede mantener en temperaturas elevadas. Como punto final, el análisis microbiológico demostró que el producto se encuentra bajo los parámetros de la Norma Técnica Ecuatoriana, considerando también que en aspectos sensoriales y con las características organolépticas cumplieron con la normativa y como consecuencia la gelatina estaría lista para ser introducida en el mercado y empezar su comercialización.

\section{REFERENCIAS BIBLIOGRÁFICAS}

Alipal, J., Mohd, N., Lee, T., Nayan, N., Sahari, N., Basri, H., Idris, M. I., \& Abdullah, H. Z. (2020). A review of gelatin: Properties, sources, process, applications, and commercialisation. Materials Today: Proceedings, 42, 240-250. https://doi.org/10.1016/j.matpr.2020.12.922

Casas, J., Albarracín, I., \& Cortés, C. (2017). Gastronomía molecular. Una oportunidad para el aprendizaje de la química experimental en contexto. TED: Tecné, Episteme y Didaxis, 2(42), 125-142. https://doi.org/10.17227/01203916.6967

Cochran, W. G., \& Cox, G. M. (1981). Diseños experimentales (p. 519). México: Trillas.

Das, N., Triparthi, N., Basu, S., Bose, C., Maitra, S., \& Khurana, S. (2015). Progress in the development of gelling agents for improved culturability of microorganisms. Frontiers in Microbiology, 6. https://doi.org/10.3389/fmicb.2015.00698

Du, L., Keplová, L., Khiari, Z., \& Betti, M. (2014). Preparation and characterization of 
gelatin from collagen biomass obtained through a pH-shifting process of mechanically separated turkey meat. Poultry Science, 93(4), 989-1000. https://doi.org/10.3382/ps.2013-03609

Greiff, S., Niepel, C., \& Wüstenberg, S. (2015). 21st century skills: International advancements and recent developments. Thinking Skills and Creativity, 18, 1-3. https://doi.org/10.1016/j.tsc.2015.04.007

Hernández, R. (2013). Robert Koch entre caldos, gelatinas, tinciones y bacilos: Crónica de un acontecimiento. Hechos Microbiológicos, 4(1), 61-83. http://aprendeenlinea.udea.edu.co/revistas/index.php/hm/article/view/20105/16978

Koppmann, M. (2011). Manual de gastronomia (El encuentro entre la ciencia y la $\begin{array}{llll}\text { cocina }) . \quad \text { XXI SIGLO VEINTIUNO } & \text { EDITORES. }\end{array}$ https://drive.google.com/file/d/0BxnSwNnzi9_TdEFNcGtwaW5NMGs/view?pli=1 Marlin, D., Gonzalez, O., \& Constantino, J. (2012). Sustancias utilizadas como agente gelificante alternativas al agar en medios de cultivo para propagación in vitro. Revista de Investigación Agraria y Ambiental, 3(2), 49-62. https://www.redalyc.org/pdf/4759/475948929012.pdf

Noguera, F., Gigante, S., Menoni, C., Aude, I., Montero, D., \& Peña, N. (2018). Principios de la preparación de alimentos. Comisión Sectorial de Enseñanza (CSE) de la Universidad de la República. https://www.cse.udelar.edu.uy/wpcontent/uploads/2018/12/Principios-de-la-preparación-de-alimentos-Noguera2018.pdf

Norma Técnica Ecuatoriana. (2019). INEN 1521.

Rehman, W., Majeed, A., Mehra, R., Bhushan, S., Rani, P., Saini, K. C., \& Bast, F. (2016). Gelatin: A comprehensive report covering its indispensable aspects. Natural Polymers: Derivatives, Blends and Composites, Volume I, September, 209-222.

Rhein, N., Ale, M., \& Meyer, A. (2015). Seaweed hydrocolloid production: An update on enzyme assisted extraction and modification technologies. Marine Drugs, 13(6), 3340-3359. https://doi.org/10.3390/md13063340

Spotti, M. (2013). Estudio de propiedades y estructura de geles mixtos proteínapolisacárido. Influencia de la reacción de glicosilación [Universidad Nacional del Litoral].

https://bibliotecavirtual.unl.edu.ar:8443/bitstream/handle/11185/658/tesis.pdf?sequ ence $=1$ 
Villalobos, A., Calderón, L., Figueroa, C., Fierro, J., Otálora, G., Álvarez, R., Quevedo, B., Mercado, M., \& Huertas-Valero, M. Trespalacios-Rangel, A. (2007). Evaluación por método ecométrico de agar obtenido de algas rojas colombianas. Universitas Scientiarum, 12(3), 57-65. https://www.redalyc.org/pdf/499/49912306.pdf

\section{PARA CITAR EL ARTÍCULO INDEXADO.} transparente talladas en 3D. Magazine De Las Ciencias: Revista De Investigación E Innovación, 6(2), 44-53. https://doi.org/10.33262/rmc.v6i2.1249 